Shinji Ishikawa • Mikio Kai • Yasushi Murata

Mayumi Tamari · Yataro Daigo · Takeshi Murano

Michio Ogawa • Yusuke Nakamura

\title{
Genomic organization and mapping of the human activin receptor type IIB (hActR-IIB) gene
}

Received: August 11, 1997/Accepted: October 22, 1997

\begin{abstract}
Activins, members of a family of proteins that includes transforming growth factor-beta (TGF-beta), are gonadal polypeptide hormones that stimulate secretion of follicle-stimulating hormone (FSH). During large-scale sequencing analysis of a 1.2-Mb fragment of human genomic DNA on 3p22-p21.3, we found the gene encoding activin receptor type IIB (hActR-IIB). Comparison of its reported cDNA sequence with this genomic sequence showed that the $h A c t R-I I B$ gene consists of 11 exons and spans about $30 \mathrm{~kb}$ of genomic DNA.
\end{abstract}

Key words Genomic structure · Activin receptor · Largescale DNA sequencing

Activins, members of a family of proteins that includes transforming growth factor-beta (TGF- $\beta)$, are gonadal polypeptide hormones that stimulate secretion of folliclestimulating hormone (FSH) in pituitary cells (Eto et al. 1987). Activins are widely expressed during murine development; they are highly conserved among vertebrates and may be involved in induction of mesoderm (Smith et al. 1990; Thomsen et al. 1990). In humans, expression of activin mRNA in the bone marrow and spleen, and secretion of this hormone by peripheral blood monocytes, suggest that activin acts as a natural regulator of erythropoiesis in the bone marrow (Eramaa et al. 1992).

The function of activin is mediated by binding to serine/ threonine kinase receptors type I and type II (Massague

S. Ishikawa · M. Kai · Y. Murata · M. Tamari · Y. Daigo · T. Murano · Y. Nakamura $(\bowtie)$

Laboratory of Molecular Medicine, Human Genome Center, Institute of Medical Science, The University of Tokyo, 4-6-1

Shirokanedai, Minato-ku, Tokyo 108-8639, Japan

Tel.: +81-3-5449-5372, Fax: +81-3-5449-5433

e-mail: yusuke@ims.u-tokyo.ac.jp,

S. Ishikawa $\cdot$ M. Ogawa

Department of Surgery II, Kumamoto University Medical School, Kumamoto, Japan

Y. Nakamura

Department of Genome Analysis, Cancer Institute, Tokyo, Japan
1992). The type II receptor has two homologues, ActR-II and ActR-IIB; both are transmembrane proteins, each with an extracellular ligand-binding domain and an intracellular kinase domain related to serine/threonine kinases (Mathews and Vale 1991; Attisano et al. 1992). The human activin receptor type IIB (hActR-IIB) cDNA, first cloned by Hilden et al. in 1994, encodes 512 amino acids containing an extracellular ligand-binding domain, a hydrophobic transmembrane domain, and an intracellular serine/threonine kinase domain (Hilden et al. 1994).

During a DNA-sequencing analysis of nearly 685 kilobases of human chromosome 3 p21.3, a fragment that includes the region that is homozygously deleted in a lungcancer cell line, we detected five genes by cDNA screening combined with two computer programs, GRAIL2 (Xu et al. 1994) and HEXON (Solovyev et al. 1994). As four of them (trans-Golgi p230, Integrin aRLC, HYA22, villin-like) were removed by the homozygous deletion, we considered them to be candidates for a putative tumor suppressor gene, but we found no somatic mutations in any of the lung or renalcell carcinomas we examined (Ishikawa et al. 1997). Then, we considered that the homozygous deletion might exert a positional effect by influencing expression of genes in the near vicinity. We therefore extended the DNA sequencing beyond the borders of the deletion and detected two genes; one encoded phospholipase C delta 1 (PLCD1) (Ishikawa et al. 1997). Here, we report the genomic structure of the other, $h A c t R-I I B$.

On the basis of our contig map, two cosmid clones (575 and 424) were considered to be located about $500 \mathrm{~kb}$ telomeric to the telomeric breakpoint of the homozygous deletion in the lung-cancer cell line. We digested these clones by sonication and subcloned $1.5-$ to $6.0-\mathrm{kb}$ fragments into pBluescript II SK(-). We picked 300 subclones, digested the plasmid clones with EcoRI and XhoI, and electrophoresed the products on a $0.8 \%$ agarose gel to check the sizes of inserted fragments and to eliminate clones containing vector sequences by hybridization with $\left[{ }^{32} \mathrm{P}\right] \mathrm{dCTP}$-labeled cosmid vector. Selected clones were sequenced at both ends with T3 and T7 dye terminator using an ABI 377 autosequencer. DNA sequences were assembled by means of the ABI "As- 
sembler" computer software. Gaps between the assembled segments were connected by direct-cosmid sequencing using primers designed from the end sequences of the assembled segments. Within the 52,985-bp sequence (GenBank accession no. AB008681) obtained from the two cosmid clones, the GRAIL2 program predicted 13 possible exons with an "excellent" score. Homology analyses of these computerpredicted exons by means of the FASTA program revealed that 9 of the fragments were identical to parts of the cDNA encoding human activin receptor type IIB (hActR-IIB). A comparison of genomic DNA sequences with the cDNA sequence revealed that this gene consisted of 11 exons and spanned about $30 \mathrm{~kb}$ (Fig. 1). The exon containing the initiation codon was contained in cosmid 575; the other 10 exons were contained in cosmid 424. Sequences of the exon-intron boundaries are given in Table 1.

Table 1 Exon - intron boundary sequence of $h A c t R-I I B$ gene

\begin{tabular}{|c|c|c|c|c|c|c|}
\hline $\begin{array}{l}\text { Exon } \\
\text { number }\end{array}$ & $\begin{array}{l}\text { Exon length } \\
\text { (bp) }\end{array}$ & $\begin{array}{l}\text { cDNA } \\
\text { position }\end{array}$ & Splice acceptor & Splice donor & $\begin{array}{l}\text { Intron } \\
\text { number }\end{array}$ & $\begin{array}{l}\text { Intron length } \\
\text { (bp) }\end{array}$ \\
\hline 1 & 56 & $1-56$ & & CTGTGCGCCG gtaagaactg & 1 & 22922 \\
\hline 2 & 208 & $57-264$ & tggggcacag GCTCTGGGCG & GCTACGATAG gtaccccaag & 2 & 366 \\
\hline 3 & 110 & $265-374$ & gtgcctccag GCAGGAGTGT & GGCCGGAAG gtaagggggc & 3 & 170 \\
\hline 4 & 152 & $375-526$ & tgtcccccag TCACGTACGA & CATCCATGAG gtgagacagt & 4 & 82 \\
\hline 5 & 144 & $527-670$ & tctcccccag GACCCTGGGC & CCCACTCCAG gtgagtgttt & 5 & 609 \\
\hline 6 & 144 & $671-814$ & ccggectcag GACAAGCAGT & CCATGACAAG gtgagccaca & 6 & 407 \\
\hline 7 & 149 & $815-963$ & cttctctcag GGCTCCСТCA & TTGCCCACAG gtacctgggt & 7 & 1524 \\
\hline 8 & 115 & $964-1078$ & gtttccacag GGACTTTAAA & CCACGGACAG gtaacaggec & 8 & 742 \\
\hline 9 & 139 & $1079-1217$ & cctcacatag GTAGGCACGA & GCTGCAGACG gtaagtagga & 9 & 95 \\
\hline 10 & 131 & $1218-1348$ & tttctcctag GACCCGTGGA & GAAACACCCG gtaggggcc & 10 & 577 \\
\hline 11 & 239 & $1349-1587$ & tgctgcttag GGCCTGGCCC & & & \\
\hline
\end{tabular}

Accession number of $h A c t R-I I B$ cDNA sequence is X77533.

Fig. 1 Location of the $h A c t R-I I B$ gene and the two cosmid clones $(575,424)$ relative to the five genes known to lie within the $1.2-\mathrm{Mb}$ region at chromosome 3p22-p21.3 that is homozygously deleted in a lung-cancer cell line. The genomic structure of $h A c t R-I I B$ is represented schematically; exons and introns are denoted by boxes and horizontal lines, respectively. Filled portions of the boxes are coding regions, and open areas are untranslated. Arrows indicate the transcriptional direction of each gene. PLCD1, phospholipase $\mathrm{C}$ delta 1

Fig. 2 Chromosomal mapping of the $h A c t R$ $I I B$ gene. a Metaphase chromosomes stained with propidium iodide show twin-spot signals on the short arm of chromosome 3 (indicated by arrows). b G-band pattern of the same metaphase chromosomes, delineated through a UV-2A filter (Nikon), indicates that the $h A c t R$ $I I B$ gene hybridized to chromosome $3 \mathrm{p} 22-21.3$
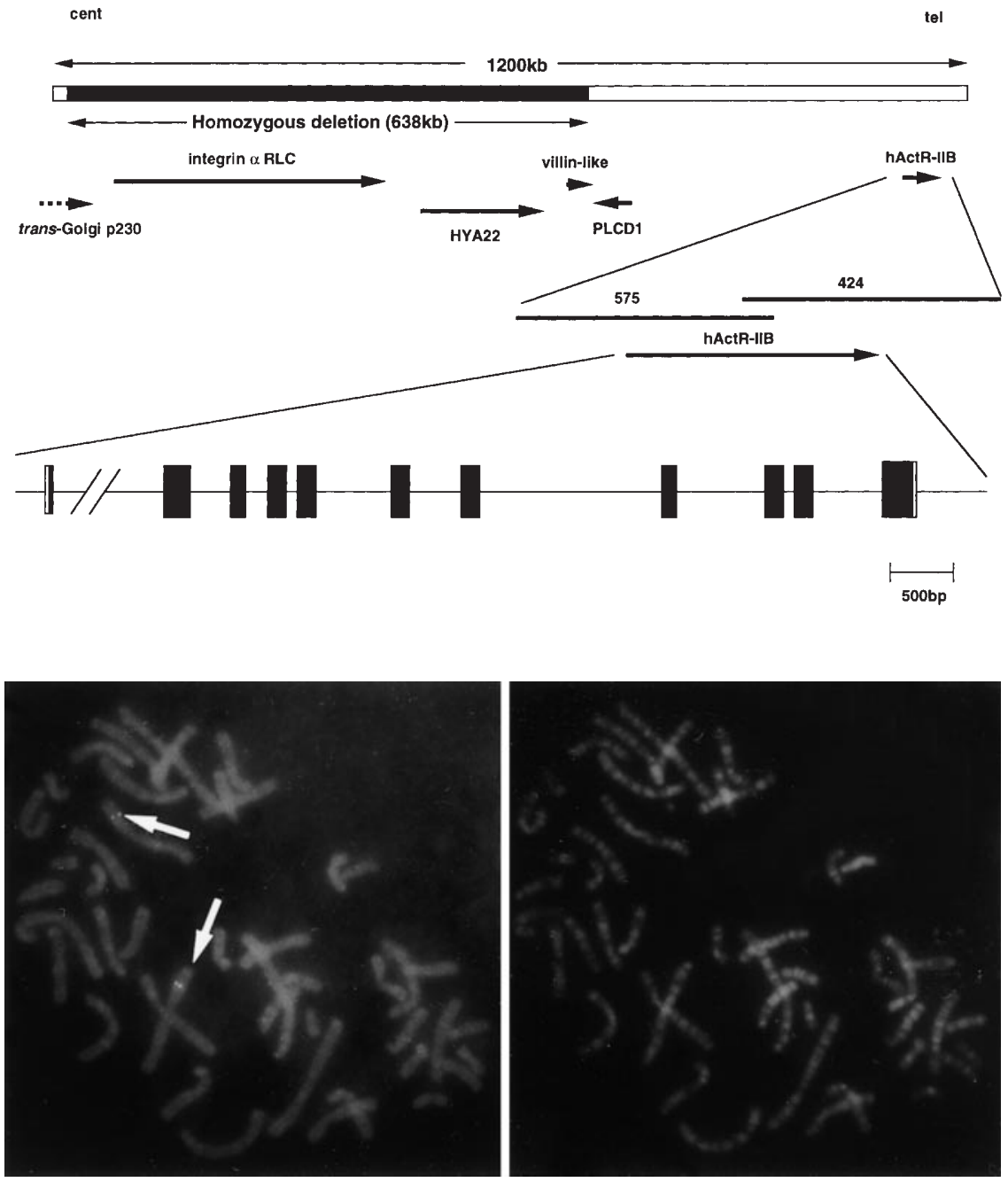
To confirm the localization of this gene, we performed fluorescence in situ hybridization (FISH) (Inazawa et al. 1993). Cosmid clone 424 was labeled with biotin-16-dUTP by nick-translation and hybridized to denatured metaphase chromosomes prepared by the thymidine synchronization/ bromodeoxyuridine release technique for the delineation of G-banding patterns. As we expected, the hybridization signals were seen specifically on chromosomal band 3p2221.3 (Fig. 2).

The region where we have been performing sequencing analysis, part of which is homozygously deleted in a lungcancer cell line, shows frequent loss of heterozygosity in carcinomas of the lung, uterus, esophagus, or kidney (Yamakawa et al. 1991; Yokoyama et al. 1992; Hibi et al. 1992) Activin reportedly induces terminal differentiation in K562 cells and limits their proliferation (Yu et al. 1987), and a related protein, a-inhibin, is known to act as a tumorsuppressor gene in mice (Matzuk et al. 1992). However, their receptors may or may not have similar functions.

Acknowledgments We thank Kumiko Takeuchi, Yuka Yamane, Tomoko Suzuki, and Mika Kobayashi for their excellent technical assistance. This work was supported in part by a special grant for Strategic Advanced Research on Cancer from the Ministry of Education, Culture, Sports, and Science of Japan; and a "Research for the Future" Program Grant (96L00102) of The Japan Society for the Promotion of Science.

\section{References}

Attisano L, Wrana JL, Cheifetz S, Massague J (1992) Novel activin receptors: Distinct genes and alternative mRNA splicing generate a repertoire of serine/threonine kinase receptors. Cell 68: 97-108

Eramaa M, Hurne M, Stenman UH, Ritvos O (1992) Activin A/ erythroid differentiation factor is induced during human monocyte activation. J Exp Med 176: 1449-1452

Eto Y, Tsuji T, Takezawa M, Takano S, Yokogawa Y, Shiba H (1987) Purification and characterization of erythroid differentiation factor (EDF) isolated from human leukemia cell line THP-1. Biochem Biophys Res Commun 142: 1095-1103
Hibi K, Takahashi T, Yamakawa K, Ueda R, Sekido Y, Ariyoshi Y, Suyama M, Takagi H, Nakamura Y, Takahashi T (1992) Three distinct regions involved in $3 p$ deletion in human lung cancer. Oncogene 7: 445-449

Hilden K, Tuure T, Eramaa M, Ritvos O (1994) Expression of type II activin receptor genes during differentiation of human K562 cells and cDNA cloning of the human type IIB activin receptor. Blood 83: 2163-2170

Inazawa J, Saito H, Ariyama T, Abe T, Nakamura Y (1993) Highresolution cytogenetic mapping of 342 new cosmid markers including 43 RFLP markers on human chromosome 17 by fluorescence in situ hybridization. Genomics 17: 153-162

Ishikawa S, Kai M, Tamari M, Takei Y, Takeuchi K, Bandou H, Yamane Y, Ogawa M, Nakamura Y (1997) Sequence analysis of a $685-\mathrm{kb}$ genomic region on chromosome 3p22-p21.3 that is homozygously deleted in a lung carcinoma cell line. DNA Res 4: 35-43

Ishikawa S, Takahashi T, Ogawa M, Nakamura Y (1997) Genomic structure of the human PLCD1 (phospholipase C delta 1) locus on 3p22-p21.3. Cytogenet Cell Genet 78: 58-60

Massague J (1992) Receptors for TGF-beta family. Cell 69:1067-1070

Mathews LS, Vale WW (1991) Expression cloning of an activin receptor, a predicted transmembrane serine kinase. Cell 65: 973 982

Matzuk MM, Finegold MJ, Su J-GJ, Hsueh AJW, Bradley A (1992) Alpha-inhibin is a tumour suppressor gene with gonadal specificity in mice. Nature 360: 313-319

Smith JC, Price BMJ, Van Nimmen K, Huylebroeck D (1990) Identification of a potent Xenopus mesoderm-inducing factor as a homologue of activin A. Nature 345: 729-721

Solovyev VV, Salamov AA, Lawrence CB (1994) Predicting internal exons by oligonucleotide composition and discriminant analysis of spliceable open reading frames. Nucleic Acids Res 22: 5156-5163

Thomsen G, Woolf T, Whitman M, Sokol S, Vaughan J, Vale W, Melton DA (1990) Activins are expressed early in Xenopus embryogenesis and can induce axial mesoderm and anterior structures. Cell 63: 485-493

Xu Y, Mural RJ, Uberbacher EC (1994) Constructing gene models from accurately predicted exons; an application of dynamic programming. Comput Appl Biosci 10: 613-623

Yamakawa K, Morita R, Takahashi E, Hori T, Ishikawa J, Nakamura Y (1991) A detailed deletion mapping of the short arm of chromosome 3 in sporadic renal cell carcinoma. Cancer Res 51: 4707-4711

Yokoyama Y, Yamakawa K, Tsuchiya E, Murata M, Sakiyama S, Nakamura Y (1992) Deletion mapping on the short arm of chromosome 3 in squamous cell carcinoma and adenocarcinoma of the lung. Cancer Res 52: 873-877

Yu J, Shao L, Lemas V, Yu AL, Vaughan J, Rivier J, Vale W (1987) Importance of FSH-releasing protein and inhibin in erythrodifferentiation. Nature 330: 765-767 